\title{
Economic policy uncertainty and overinvestment: evidence from Korea
}

\author{
Wenwen Jiang and Hwa-Sung Kim \\ School of Management, Kyung Hee University, Seoul, Republic of Korea
}

\begin{abstract}
The authors show that there is a negative relationship between economic policy uncertainty (EPU) and firm overinvestment using Korean data from 2007 to 2016. Since Jensen (1986) shows that a firm's free cash flow is an important factor of overinvestment, the authors examine how free cash flow influences the sensitivity of overinvestment to EPU. The authors find that a high level of free cash flow attenuates the negative effect of EPU on overinvestment. The authors find that there is no significant difference in the effect of EPU on overinvestment between Chaebol (Korean family-run conglomerates) and non-Chaebol firms, which is consistent with the literature that the features of Chaebol are weakening.
\end{abstract}

Keywords Economic policy uncertainty, Overinvestment, Free cash flow, Chaebol

Paper type Research paper

\section{Introduction}

The investment-uncertainty relation has been one of the most interesting research topics for a long time. The theories on the investment-uncertainty relationship have conflicting results: positive (e.g. Abel, 1983) or negative (e.g. Bernanke, 1983) relation. The sign of the relationship depends on various assumptions (Caballero, 1991). However, the empirical results generally coincide. In other words, they show a negative relationship between investment and uncertainty (Leahy and Whited, 1996; Bulan, 2005; Bloom et al., 2007; Panousi and Papanikolaou, 2012; Gulen and Ion, 2016; Jens, 2017).

Research on this relationship evokes studies on inefficient investment under uncertainty, especially for the relation between overinvestment and uncertainty. Liu (2013) shows that uncertain future policy leads to overinvestment in wind power capacity in China. Ahuja and Novelli (2017) examine overinvestment in research and development under uncertainty. Wang et al. (2016) provide empirical evidence of a negative relation between overinvestment and inflation uncertainty. Recently, Irawan and Okimoto (2021) investigate overinvestment under macroeconomic uncertainties using a sample of resource firms in 32 countries. They show that commodity price inflation and the business cycle of the home country influence overinvestment.

In line with the literature, we examine how economic policy uncertainty (hereafter, EPU) affects overinvestment using a sample of Korean firms. We develop two hypotheses regarding the overinvestment-EPU relationship. The first hypothesis is related to the

\section{JEL Classification — D81, G18, G31, G41}

(C) Wenwen Jiang and Hwa-Sung Kim. Published in Journal of Derivatives and Quantitative Studies: 선물연구. Published by Emerald Publishing Limited. This article is published under the Creative Commons Attribution (CC BY 4.0) licence. Anyone may reproduce, distribute, translate and create derivative works of this article (for both commercial and non-commercial purposes), subject to full attribution to the original publication and authors. The full terms of this licence maybe seen at http://creativecommons.org/licences/by/4.0/legalcode

The authors are grateful to the anonymous reviewers and the editor, Sol Kim for valuable and detailed comments. All errors are our responsibility.

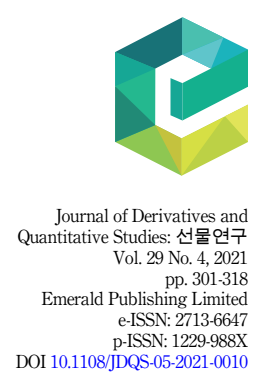


JDQS 29,4

302

empirical result of Gulen and Ion (2016). They show a negative effect of EPU on corporate investment. Consistent with their finding, we hypothesize that corporate overinvestment is negatively related to EPU. This hypothesis stems from the recent empirical results of Panousi and Papanikolaou (2012). They show that managers' poor diversification and risk aversion lead to the negative investment-uncertainty relation. Furthermore, this negative relation is stronger when manager shareholding (i.e. insider ownership) is higher, and the insider ownership effect decreases with the institutional ownership. High insider ownership induces them to act in their best interests such as inefficient investment. Hence, from the effect of insider ownership on the relationship between investment and uncertainty, we infer that overinvestment is negatively related to EPU.

Our second hypothesis is that the negative overinvestment-EPU relation is weaker for firms holding a higher level of free cash flow. This hypothesis is based on well-known theoretical and empirical results in corporate finance. Many researchers have studied the relation between overinvestment and free cash flow. Theoretical (Jensen, 1986; Stulz, 1990) and empirical (Richardson, 2006) studies argue that firms holding plenty of free cash flow are more likely to over-invest. Hence, we examine how the effect of EPU on overinvestment varies according to a firm's free cash flow. We infer from the existing literature that overinvestment is less sensitive to EPU when firms have a higher level of free cash flow.

This study makes three contributions to the literature. First, we consider EPU out of the other types of uncertainties. As stated previously, various uncertainties affect corporate overinvestment tendencies. However, there are relatively fewer papers that study the EPU effects on overinvestment. Second, we complement recent studies by focusing on the EPU effects in a country. Irawan and Okimoto (2021) provide which uncertainty influences the overinvestment of renewable and non-renewable resource firms using the global EPU index. In contrast, we provide empirical evidence of how the domestic EPU affects the overinvestment tendency of overall firms in one country. Third, as stated previously, our firm-level data allows us to consider a firm's characteristics such as its level of free cash flow.

We analyze a sample of non-financial firms listed in the Korean stock market. Our sample covers 9,942 firm-quarter observations between 2007 and 2016. We utilize the EPU index of Korea created by Baker et al. (2016). They measure EPU by calculating the number of newspaper articles that include the words related to uncertainty and policy. In addition, we construct an indicator variable of overinvestment based on Biddle et al. (2009): overinvestment is regarded as a firm's investment beyond its growth opportunity. We find that firms' tendency toward overinvestment has a negative relationship with EPU. A one-unit increase in the EPU index is associated with a decrease of $18.5 \%$ in the probability of a firm's overinvestment. This implies that firm overinvestment in Korea decreases with EPU.

Moreover, we find that a higher level of free cash flow attenuates the negative impact of $\mathrm{EPU}$ on the tendency toward overinvestment. A one-standard-deviation increase in free cash flow decreases $9.2 \%$ of the effect of EPU on overinvestment. In addition, since the Korean conglomerate (known as Chaebol) is one of the most notable features of the Korean economy, we also investigate this effect between Chaebol and non-Chaebol firms [1]. Interestingly, we find that there is no statistically significant difference in the effect of EPU on overinvestment between Chaebol and non-Chaebol firms. This is consistent with the recent observation that many features of Chaebol are weakening.

The rest of our study is organized as follows. Section 2 describes the hypotheses development. Variable definitions and research design are discussed in section 3 . Sections 4 presents the empirical results. Section 5 provides the robustness tests. Section 6 concludes. 


\section{Hypothesis development}

Our first hypothesis is on how overinvestment is related to EPU. As stated previously, empirical studies show a negative investment-uncertainty relationship. Among them, we need to scrutinize Panousi and Papanikolaou (2012) to develop our hypothesis. They show that since managers are risk-averse and exposed to idiosyncratic risk, they reduce investment as uncertainty becomes high. In other words, managerial risk aversion is a salient factor that causes the negative investment-uncertainty relation. For firms with a higher level of insider ownership (the percentage of shares held by a firm's managers), investment is more sensitive to uncertainty. Furthermore, Panousi and Papanikolaou (2012) find that this sensitivity becomes weaker as institutional ownership increases because large institutional investors can more effectively monitor managers' behavior.

From their findings, we infer that overinvestment as an inefficient investment is negatively related to EPU. When uncertainty increases, poorly diversified (or undiversified) and riskaverse managers will be willing to decrease investment, and therefore, avoid overinvestment. On the contrary, when the level of uncertainty decreases, managers increase investment. Furthermore, Panousi and Papanikolaou (2012) show that the negative investment-uncertainty relationship is stronger for firms with higher insider ownership. High insider ownership provides managers with a stronger incentive to behave in their best interests including inefficient investments such as overinvestment. This tendency toward overinvestment is stronger with insider ownership. Hence, we infer that the negative investment-uncertainty relationship can be extended to the relationship between overinvestment and uncertainty, that is, EPU.

\section{H1. Overinvestment is negatively related to EPU.}

Our second hypothesis is on how the negative effect of EPU on overinvestment differs according to a firm's free cash flow. The relationship between overinvestment and free cash flow is related to an important research topic in corporate finance: investment-cash flow sensitivity. According to Abel (1983), corporate investment should be insensitive to free cash flow in a perfect market. However, empirical results show a positive investment-cash flow relationship due to financial constraints (e.g. Fazzari et al., 1988) [2].

In accordance with the literature, both theoretical and empirical papers study the relationship between overinvestment and free cash flow. Jensen (1986) demonstrates that firms are more likely to over-invest when they have plenty of free cash flow, which is referred to as the free cash flow problem. Harford (1999) shows that firms with plenty of cash tend to make value-decreasing acquisitions. Richardson (2006) empirically tests the free cash flow problem, measuring overinvestment by filtering out firms' growth opportunities from investments. His result supports the free cash flow hypothesis. From these results, we connect firms' free cash flow with the relationship between overinvestment and EPU. We need to examine the relationship between overinvestment and EPU considering a firm's free cash flow. We infer from the findings in the literature that the impact of EPU on overinvestment is weaker for firms with higher levels of free cash flow.

\section{H2. Overinvestment in firms with more free cash flow is less affected by EPU.}

Next, we examine whether there is a difference in EPU effect on overinvestment between Chaebol and non-Chaebol firms. A Chaebol is a business conglomerate of several companies with highly concentrated ownership. It has made an outstanding contribution to Korean economic growth during the past 50 years (Baek et al., 2004). Previous studies demonstrate many features of Chaebol firms that are related to overinvestment behavior. First, Chaebol firms experience the lack of investment efficiency due to being highly diversified in unrelated fields. Ferris et al. (2003) show that Chaebol firms continue to invest in their affiliates even when the affiliate shows low growth. This indicates that Chaebol firms
EPU and
overinvest-
ment

303 
JDQS

29,4

have weaker investment-uncertainty sensitivity than non-Chaebol firms based on the development of Hypothesis 1, and thus, a lower overinvestment-uncertainty sensitivity. Second, Chaebol firms possess internal capital markets and a higher debt capacity compared with non-Chaebol firms (Shin and Park, 1999; Ferris et al., 2003). Pástor and Veronesi (2013) demonstrate that the rise in the cost of external financing under political uncertainty leads to the decreases in investment. As a result, the internal capital markets and higher debt capacity provide Chaebol firms with the fund for overinvestment. Therefore, we draw the following hypothesis.

H3a. Overinvestment of Chaebol firms is less sensitive to EPU.

However, recent papers argue that many characteristics of Chaebol firms have been disappearing, especially after the 1997 Asian crisis. Borensztein and Lee (2002) show that Chaebol firms lost the priority in debt market that they had before the crisis of 1997. Lee et al. (2009) find that the internal capital markets inside Chaebol firms lost their significance after the crisis and are substituted by public debt markets. Furthermore, Goh et al. (2016) provide evidence that the overinvestment of Chaebol firms significantly decreased after the Asian financial crisis. Thus, this phenomenon regarding Chaebol firms provides the following hypothesis.

H3b. The effect of EPU on overinvestment for Chaebol firms is not significantly different from that of non-Chaebol firms.

\section{Methodology}

\subsection{Sample}

We obtain our sample from firms listed in the KOSPI market. We require firm-quarter observations to have valid information about total assets and sales. We utilize quarterly data from the DataGuide database [3]. We obtain information about Chaebol firms from the Korean Fair Trade Commission (KFTC) [4]. We also employ the Korean monthly EPU index developed by Baker et al. (2016) [5]. The financial firms are excluded from our sample. Finally, our sample consists of 9,942 firm-quarter observations from 2007 to 2016.

\subsection{Construction of variables}

3.2.1 Economic policy uncertainty. The proxies of EPU mainly used in the literature are the election-based indicator variables (Julio and Yook, 2012; Jens, 2017) and a monthly index representing the level of EPU (Baker et al., 2016). This paper utilizes the index developed by Baker et al. (2016) as the main proxy for Korean EPU. As pointed by Gulen and Ion (2016), an election-based proxy fails to capture the variation of EPU during years without an election. However, using the time-variant EPU index makes it possible to examine how overinvestment fluctuates across the variation of EPU. Specifically, the EPU index of Korea is measured using the number of articles related to economy, uncertainty and policy, published in the six most influential Korean newspapers [6]. To match the monthly EPU index with other data of our research, we calculate the arithmetic average of the monthly index within each quarter and take its natural logarithm (Gulen and Ion, 2016).

3.2.2 Overinvestment. We follow Biddle et al. (2009) to measure a firm-level overinvestment, where they define overinvestment as the excessive investment unexplained by growth opportunities. They use a firm's sales growth as a proxy for its growth opportunities. Investment (Inv) represents capital expenditures normalized by total assets. Sales growth (SG) is calculated as the difference in sales between quarters $t$ and $t-1$, scaled by sales in quarter $t$. 
Equation (1) delineates the regression of investment on sales growth for each quarterindustry [7].

$$
\operatorname{Inv}_{i, t}=\alpha+\beta_{1} \mathrm{SG}_{i, t-1}+\varepsilon_{i, t} .
$$

For a given quarter, a positive residual of firm $i$ from Equation (1) indicates that firm $i$ invests beyond its growth opportunities, which represents its overinvestment. We construct the variable of overinvestment as an indicator variable that equals 1 if the residual is greater than 0 and 0 if otherwise.

3.2.3 Other variables. "Free cash flow is cash flow in excess of what is required to fund all positive-NPV projects" (Jensen, 1986). Several proxies have been used in prior studies. We adopt internal funds as the proxy for free cash flow to measure the discretionary funds under managerial control (e.g. Lehn and Poulsen, 1989; Gul and Tsui, 1997; Bhagat et al., 2005) [8]. The internal funds are calculated as the sum of net profit and depreciation scaled by total assets.

We construct an indicator variable for Chaebol which equals 1 if a firm belongs to a Chaebol group in a given year, 0 otherwise [9]. We also consider the effects of firm characteristics by incorporating control variables in our model. The control variables are cash holding, firm leverage (Jensen, 1986; Duchin et al., 2010), firm age, firm size, tangibility (Biddle et al., 2009) and dividend payment. The variable definitions are provided in the Appendix.

\subsection{Models}

We utilize a linear probability model to estimate the impact of EPU on overinvestment because the dependent variable is binary. We also employ a logit model for robustness tests in section 5. The re-estimated results are consistent with the ones from the linear probability model. Compared with the logit model, the interpretation of the coefficients in the linear probability model is more intuitive, especially for the coefficients of interaction terms.

In Equation (2), $i, t$ and $k$ stand for firm, quarter and industry, respectively. OverI represents an indicator variable of overinvestment. $C$ represents a vector of control variables that are related to firm investment and investment efficiency. $\eta_{k}$ represents industry fixed effects. As stated in Gulen and Ion (2016), we cannot incorporate time fixed effects in our model because if time fixed effects were to be included, EPU would be explained by these effects, and hence, a multi-linearity would occur. Hence, following Gulen and Ion (2016), we control for confounding macroeconomic forces by using the quarterly growth in real GDP. We also include a set of year-quarter dummy variable $\left(\delta_{t}\right)$ to control for the seasonality of overinvestment. Based on Hypothesis 1 , the increase in $\mathrm{EPU}$ is likely to be negatively related to overinvestment. Thus, we expect $\beta_{1}$ to be negative.

$$
\operatorname{OverI}_{i, t}=\alpha_{1}+\beta_{1} \mathrm{EPU}_{t-1}+\mathrm{GDPgrowth}_{t-1}+\varphi C_{i, t-1}+\eta_{k}+\delta_{t}+\varepsilon_{i, t} .
$$

We proceed by investigating the cross-sectional heterogeneity of the relationship between EPU and overinvestment. In Equation (3), coefficient $\beta_{1}$ reflects the relationship between EPU and overinvestment. The coefficient $\beta_{2}$ shows the incremental effect from a cross-sectional heterogeneity on the relationship between EPU and overinvestment. Specifically, Het represents free cash flow and the Chaebol effect. Note that we do not include simultaneously "Het" term in the model because including the "Het" term would induce a severe problem of multi-collinearity (e.g. Duchin et al., 2010; Wang et al., 2014).

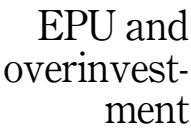


JDQS 29,4

$$
\operatorname{OverI}_{i, t}=\alpha_{1}+\beta_{1} \mathrm{EPU}_{t-1}+\beta_{2} \mathrm{EPU}_{t-1} \times \text { Het }+\operatorname{GDPgrowth}_{t-1}+\varphi C_{i, t-1}+\eta_{k}+\delta_{t}+\varepsilon_{i, t} .
$$

\section{6}

\section{Empirical results}

\subsection{Descriptive statistics}

Table 1 provides the descriptive statistics of the variables. $39.5 \%$ of our sample falls under overinvestment. The average free cash flow and investment account for 1.4 and $1.1 \%$ of total assets, respectively. Table 2 presents the Pearson correlations between variables. The result shows that overinvestment has a negative correlation with EPU. Furthermore, overinvestment is positively correlated with free cash flow, which is consistent with the literature (e.g. Jensen, 1986).

\subsection{Effect of EPU on overinvestment}

Table 3 presents the baseline result of our study. We regress overinvestment on EPU, controlling for industry fixed effects and a set of year-quarter dummies in column (1). The coefficient of EPU is negative and statistically significant. In column (2), we further consider the effect of growth in GDP and a set of control variables that affect overinvestment. The negative coefficient of EPU $(-0.248)$ remains statistically significant at the $1 \%$ level. This result indicates that a one-standard-deviation increase in EPU (0.295) decreases the probability of overinvestment by $0.073(-0.248 \times 0.295)$. Given that the sample mean of overinvestment is 0.395 , this effect is equivalent to a decrease of $18.5 \%(0.073 / 0.395)$ to the sample mean of overinvestment. This finding implies that overinvestment decreases when the level of EPU is high, which supports our Hypothesis 1.

\subsection{Impact of cross-sectional heterogeneity on the effect of EPU on overinvestment}

Table 4 reports the cross-sectionally heterogenous impacts of free cash flow and Chaebol on the relationship between overinvestment and EPU. Columns (1) and (2) show that the coefficient of the interaction term of EPU and free cash flow is positive and statistically significant even after we consider the effect of control variables. The coefficients of EPU and the interaction term in column (2) are -0.147 and 0.589 , respectively. This indicates that a

Table 1.

Descriptive statistics

\begin{tabular}{|c|c|c|c|c|c|c|c|c|}
\hline & Mean & Std. Dev & Min & $25 \%$ & Median & $75 \%$ & Max & Type \\
\hline Inv & 0.011 & 0.023 & -0.060 & 0.002 & 0.006 & 0.014 & 0.138 & Quarterly \\
\hline OverI & 0.395 & 0.489 & 0.000 & 0.000 & 0.000 & 1.000 & 1.000 & Quarterly \\
\hline $\mathrm{EPU}$ & 4.856 & 0.295 & 4.187 & 4.608 & 4.960 & 5.075 & 5.421 & Quarterly \\
\hline GDP growth & 0.009 & 0.051 & -0.076 & -0.056 & 0.009 & 0.054 & 0.068 & Quarterly \\
\hline $\mathrm{FCF}$ & 0.014 & 0.023 & -0.094 & 0.005 & 0.015 & 0.025 & 0.075 & Quarterly \\
\hline Chaebol & 0.205 & 0.403 & 0.000 & 0.000 & 0.000 & 0.000 & 1.000 & Annual \\
\hline Lev & 0.430 & 0.186 & 0.042 & 0.283 & 0.435 & 0.569 & 0.855 & Quarterly \\
\hline Age & 8.700 & 0.869 & 5.398 & 8.384 & 8.948 & 9.320 & 9.680 & Quarterly \\
\hline Size & 19.700 & 1.462 & 17.210 & 18.710 & 19.430 & 20.320 & 24.300 & Quarterly \\
\hline Cash & 0.053 & 0.055 & 0.000 & 0.014 & 0.036 & 0.075 & 0.277 & Quarterly \\
\hline Tang & 0.327 & 0.157 & 0.001 & 0.217 & 0.321 & 0.431 & 0.710 & Quarterly \\
\hline Div & 0.272 & 0.445 & 0.000 & 0.000 & 0.000 & 1.000 & 1.000 & Annual \\
\hline
\end{tabular}

Note(s): This table reports the statistics for the variables. Our sample consists of 9,942 firm-quarter observations. See Appendix for the definition of variables. All financial variables are winsorised at the 1 and $99 \%$ levels to reduce the influence of outliers 


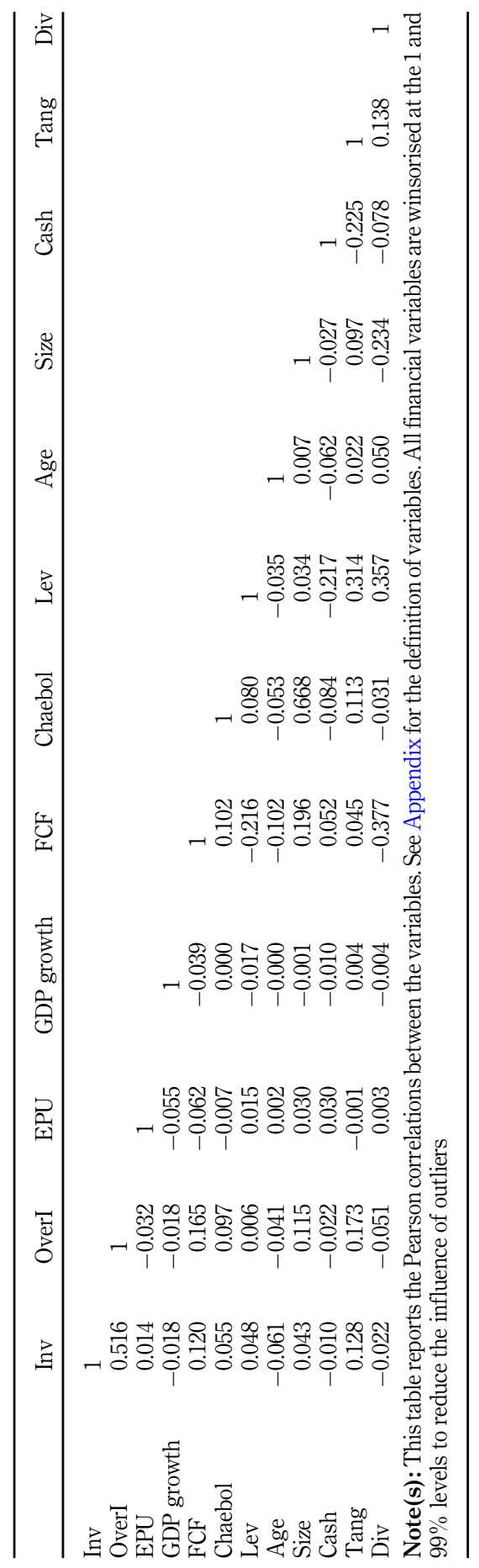

EPU and overinvestment

307

Table 2. Pearson correlations 


\section{JDQS 29,4}

(1)

(2)

\begin{tabular}{|c|c|c|}
\hline 308 & $\begin{array}{l}\text { EPU }_{t-1} \\
\text { GDPgrowth }_{t-1} \\
\text { Lev }_{t-1} \\
\text { Age }_{t-1} \\
\text { Size }_{t-1} \\
\text { Cash }_{t-1} \\
\text { Tang }_{t-1}\end{array}$ & $-0.103^{* * *}(-40.15)$ \\
\hline & $\begin{array}{l}\text { lang }_{t-1} \\
\text { Div }_{t-1} \\
\text { Industry FE } \\
\text { Quarter dummies } \\
\text { Obs } \\
\text { Adj. } R^{2}\end{array}$ & $\begin{array}{c}\text { Yes } \\
\text { Yes } \\
9,942 \\
0.010\end{array}$ \\
\hline
\end{tabular}

$$
\begin{gathered}
-0.248 * * *(-5.954) \\
0.877 * * *(4.159) \\
-0.117 * *(-1.767) \\
-0.026 * *(-2.244) \\
0.031 * * *(3.605) \\
0.060(0.363) \\
0.618 * * *(8.686) \\
-0.050 * *(-2.158) \\
\text { Yes } \\
\text { Yes } \\
9,942 \\
0.062
\end{gathered}
$$

Table 3.

The effect of EPU on overinvestment

\begin{tabular}{|c|c|c|c|c|}
\hline & (1) & (2) & (3) & (4) \\
\hline $\mathrm{EPU}_{t-1}$ & $-0.065^{* * *}(-25.30)$ & $-0.147 * * *(-3.707)$ & $-0.106^{* * * *}(-38.97)$ & $-0.235^{* * * *}(-4.818)$ \\
\hline $\mathrm{EPU}_{t-1} \times \mathrm{FCF}_{t-1}$ & $0.721 * * *(8.028)$ & $0.589 * * *(8.257)$ & & \\
\hline $\mathrm{EPU}_{t-1} \times$ Chaebol & & & $0.024 * * *(3.603)$ & 0.010 (1.415) \\
\hline GDPgrowth $_{t-1}$ & & $0.433 * *(2.025)$ & & $0.854 * * *(3.368)$ \\
\hline $\operatorname{Lev}_{t-1}$ & & $-0.061(-0.955)$ & & $-0.118^{*}(-1.782)$ \\
\hline Age $_{t-1}$ & & $-0.019 *(-1.700)$ & & $-0.025 * *(-2.134)$ \\
\hline Size $_{t-1}$ & & $0.025 * * *(3.221)$ & & $0.022 *(1.920)$ \\
\hline $\operatorname{Cash}_{t-1}$ & & $0.034(0.209)$ & & $0.072(0.433)$ \\
\hline Tang $_{t-1}$ & & $0.562 * * *(8.394)$ & & $0.618 * * *(8.671)$ \\
\hline $\operatorname{Div}_{t-1}$ & & $-0.005(-0.216)$ & & $-0.056 * *(-2.397)$ \\
\hline Industry FE & Yes & Yes & Yes & Yes \\
\hline Quarter dummies & Yes & Yes & Yes & Yes \\
\hline Obs & 9,942 & 9,942 & 9,942 & 9,942 \\
\hline Adj. $R^{2}$ & 0.037 & 0.076 & 0.019 & 0.063 \\
\hline
\end{tabular}

Note(s): This table presents the results from a linear probability model. The dependent variable is overinvestment. See Appendix for variable definitions. All financial variables are winsorised at the 1 and $99 \%$ levels to reduce the influence of outliers. We control for industry fixed effects and a set of year-quarter dummies. Standard errors are clustered on both firm and quarter level. $t$-statistics are reported in parentheses. $*, * *$ and $* * *$ indicate significance at the 10,5 and $1 \%$ levels, respectively

one-standard-deviation increase in free cash flow (0.023) is associated with a $9.2 \%$ decrease in the effect of EPU on overinvestment [10]. The result supports Hypothesis 2.

Columns (3) and (4) of Table 4 present the result for Chaebol effect on the relation between EPU and overinvestment. Column (3) shows that the coefficient of the interaction term is positive and statistically significant. However, the coefficient is not statistically significant if we consider the effects of control variables (column (4)). This indicates that the effect of

Note(s): This table presents the results of the impact from free cash flow (FCF) and Chaebol firms (Chaebol), respectively. Internal finance is measured as the sum of net profit and depreciation scaled by total assets. Chaebol is an indicator variable which takes value 1 if a firm belongs to a Chaebol group in a given year,

\section{Table 4.}

The impact of free cash flow and Chaebol on the sensitivity of overinvestment to EPU
0 otherwise. Note that Chaebol is measured annually. The results are from a linear probability model. The dependent variable is overinvestment. See Appendix for the definition of other variables. All financial variables are winsorised at the 1 and $99 \%$ levels to reduce the influence of outliers. We control for industry fixed effects and a set of year-quarter dummies. Standard errors are clustered on both firm and quarter level. $t$-statistics are reported in parentheses. $* * *$ and $* * *$ indicate significance at the 10,5 and $1 \%$ levels, respectively 
Chaebol can be explained by the control variables representing firm-specific characteristics [11]. Therefore, we find that the impact of EPU on overinvestment is not significantly different between Chaebol and non-Chaebol firms. This result supports Hypothesis $3 \mathrm{~b}$ but rejects Hypothesis 3a. Our finding provides supportive evidence to recent studies arguing that many characteristics of Chaebol firms have been disappearing after the 1997 Asian crisis (Borensztein and Lee, 2002; Lee et al., 2009; Goh et al., 2016).

\section{Robustness tests}

\subsection{Alternative statistical model}

So far, we have used the linear probability model because the coefficients in the linear probability model are more intuitive to interpret, especially for the coefficients of interaction terms. However, the fitted probabilities from estimation could be outside the range, between zero and one by construction. To confirm the robustness of our results, we re-estimate all the results in our paper using a logit model. In Table 5, columns (1) and (2) show the negative relationship between EPU and overinvestment. Columns (3) and (4) report the re-estimated results of tests conducted in Table 4, which also provide consistent support to our previous findings. Column (3) shows that free cash flow mitigates the effect of EPU on overinvestment. Column (4) shows that Chaebol and non-Chaebol firms do not respond differently to EPU. Table 5 indicates that our findings are not affected according to statistical models.

\subsection{Alternative proxies of overinvestment}

In this subsection, we employ two alternative proxies of overinvestment. In section 3 , we regress total investment on growth opportunity and consider the residual as overinvestment. This simply assumes that all investment is discretionary. However, Richardson (2006) argues that a firm's investment contains the part to maintain the operating activities irrelevant to growth opportunity. Hence, we suggest that this part

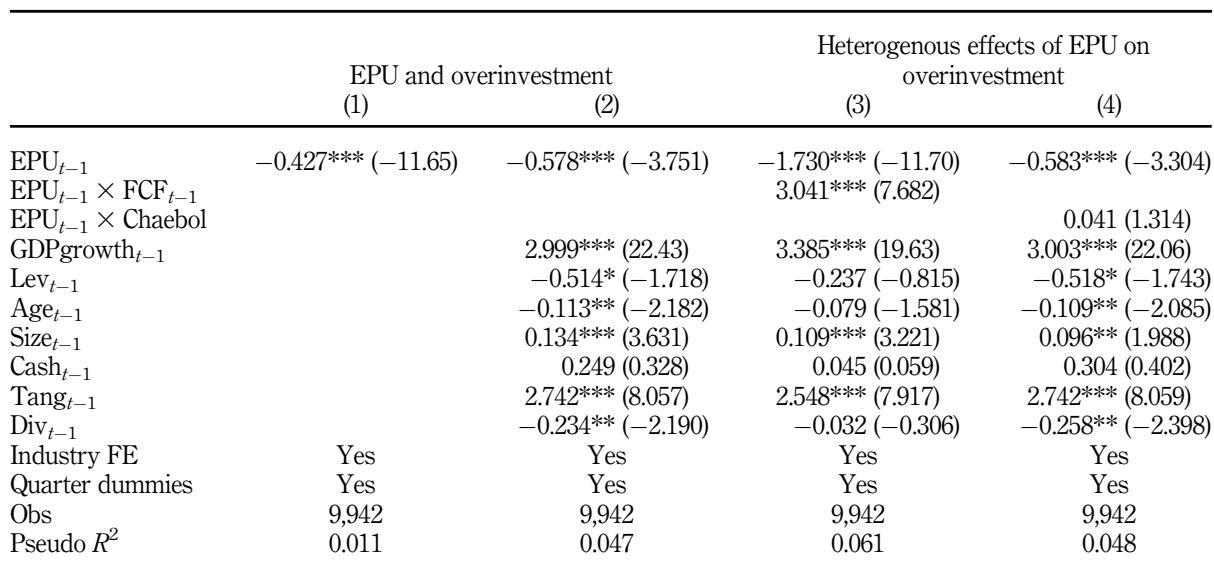

Note(s): This table presents the results using a logit model. The dependent variable is overinvestment. See Appendix for variable definitions. All financial variables are winsorised at the 1 and $99 \%$ levels to reduce the influence of outliers. We control for industry fixed effects and a set of year-quarter dummies. Standard errors are clustered on both firm and quarter level. $z$-statistics are reported in parentheses. *, ** and *** indicate significance at the 10,5 and $1 \%$ levels, respectively
EPU and overinvestment 
JDQS 29,4

should be deducted from total investment when estimating overinvestment using a model like Equation (1). Therefore, we deduct investment to maintain the current level of operation ( $\left.I_{\text {Maintain }}\right)$ from total investment as Equation (4) and use Inv $_{\text {New }}$ instead of Inv to estimate overinvestment (OverI2) as Equation (5). We use depreciation to measure $I_{\text {Maintain }}$. We then re-estimate all the results in our paper using OverI2 and present the result in Table 6.

$$
\begin{aligned}
& \operatorname{Inv}_{\text {Newi }, t}=\operatorname{Inv}_{i, t}-\operatorname{Inv}_{\text {Maintaini } i,} . \\
& \operatorname{Inv}_{\text {Newi } i t}=\alpha+\beta_{1} \mathrm{SG}_{i, t-1}+\varepsilon_{i, t} .
\end{aligned}
$$

Second, also following Richardson (2006), we regress firm investment on its growth opportunity (Tobin's q) and variables reflecting a firm's characteristics (cash holding, leverage, firm age, firm size, stock return and a lagged investment) with the controls of industry and time effects. We then construct an indicator variable for overinvestment based on the sign of the residuals: the variable OverI3 equals 1 if the residual is positive and 0 if otherwise. Note that we use only two control variables: tangibility and dividend payment. This is because other firm-specific variables (i.e. cash holding, leverage, firm age and firm size) have been used as independent variables in estimating the alternative proxy for overinvestment, OverI3. Table 6 shows the results using OverI2 and OverI3 provide the similar results as Tables 3 and 4

\subsection{Alternative proxies of free cash flow}

Our empirical results have shown that free cash flow mitigates the relationship between EPU and overinvestment. As a robustness test, we use two alternative proxies for free cash flow (FCF2 and FCF3). FCF2 is measured as retained earning scaled by total assets following Kallapur (1994), which shows that managers invest in value-decreasing projects with retained earnings. FCF3 is measured following Richardson (2006), where free cash flow is defined as cash flow beyond what is necessary to maintain current operation and finance expected new investment. We use depreciation to measure what is needed to maintain current operation and the fitted value of Equation (1) to measure cash flow to finance expected new investment, respectively. Therefore, FCF3 is calculated as operating cash flow net of both depreciation and the fitted value of Equation (1). We re-estimate the model of Equation (3) using two alternative proxies of free cash flow and find a similar result as shown in Table 7.

\subsection{Alternative proxy of EPU}

So far, our empirical tests have used the index developed by Baker et al. (2016) as a proxy for EPU. However, as pointed by Jens (2017), the source of EPU index includes not only typical economic political events but also wars, terrorist attacks and other types of events. Jens (2017) argues that even though some of these events are related to EPU, others may have no effect on the politics of a country and should not be classified as EPU. Therefore, we need to conduct a robustness test using the election as an alternative proxy for EPU.

We employ Jens' (2017) model to test the effect of the election on overinvestment:

$$
\text { OverI }_{i, t}=\alpha_{1}+\beta_{1} \text { Elect } \times Q 3+\beta_{2} \text { Elect }+\beta_{3} Q 3+\varphi C_{i, t-1}+\eta_{k}+\delta_{t}+\varepsilon_{i, t},
$$

where Elect is an indicator variable which equals 1 if the Korean presidential election occurred in the year and 0 if otherwise. There are two election years during the time span of our sample from 2007 to 2016. Q3 is an indicator variable which equals 1 for the third quarter of a year and 0 if otherwise. Using US gubernatorial elections as the source of political uncertainty, Jens (2017) shows that investment begins to decline beginning from the quarter before the election (i.e. the third quarter of the election year) [12]. Since Korean presidential 


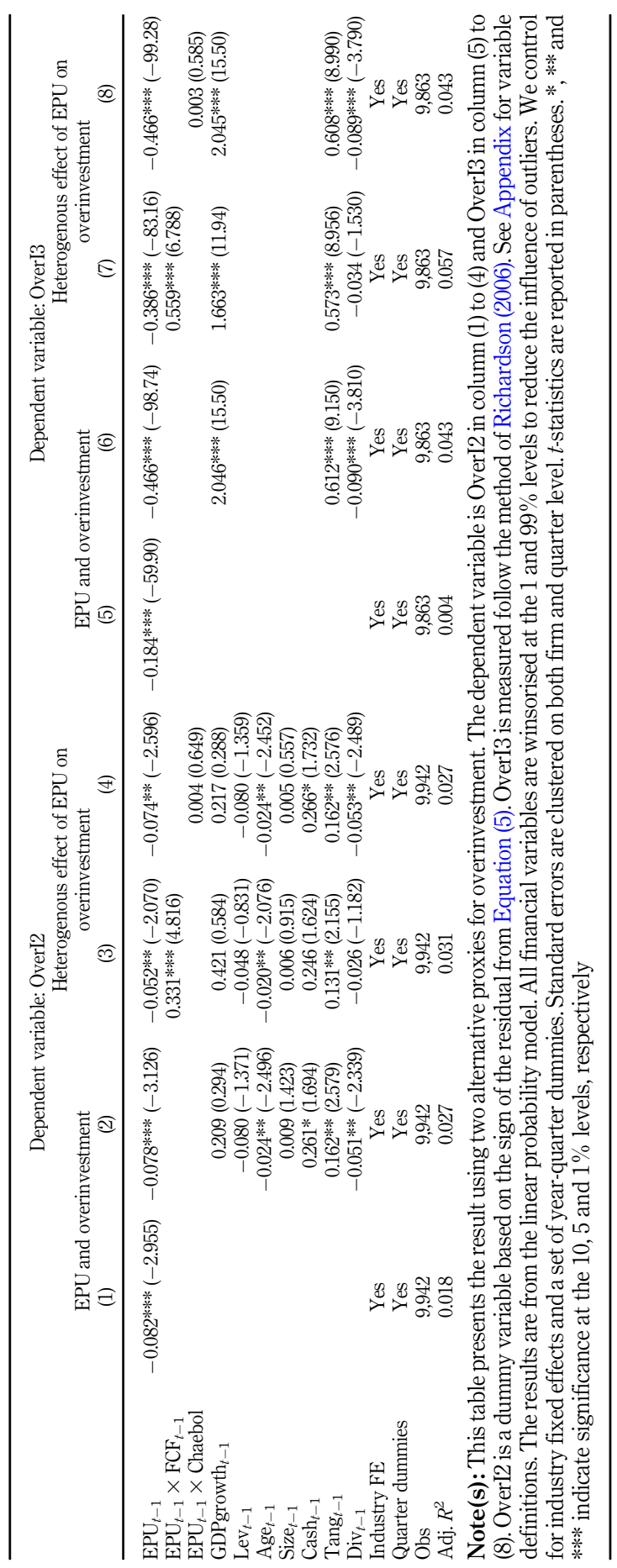

EPU and overinvestment

311

Table 6.

Robustness test using alternative proxies for overinvestment 


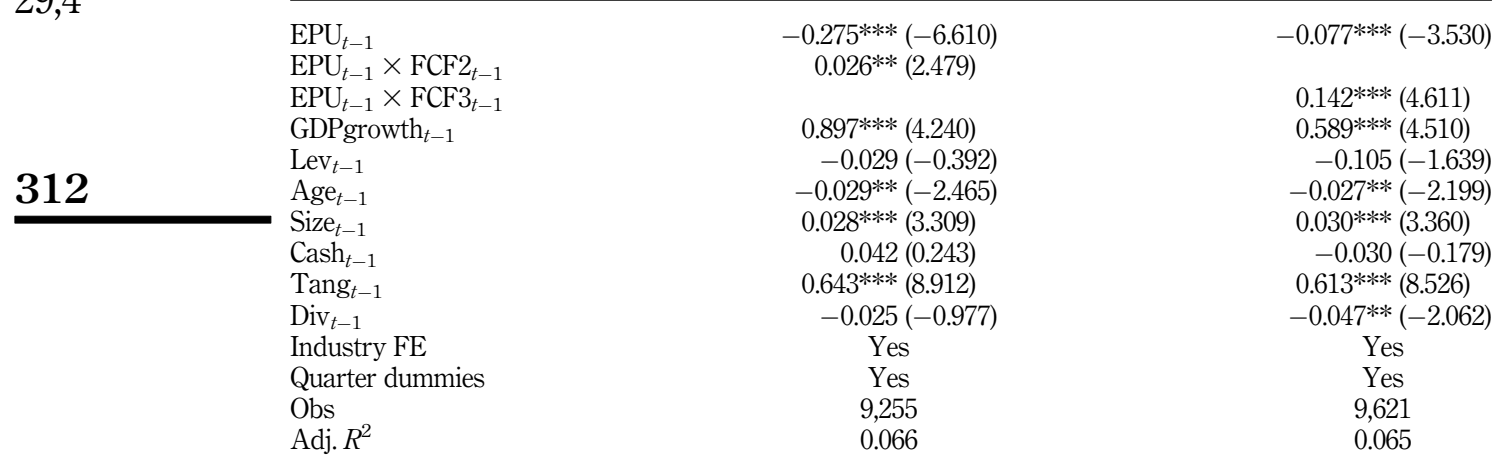

Note(s): This table presents the results of the robustness test using two alternative proxies for free cash flow (FCF2 and FCF3). The dependent variable is overinvestment. FCF2 is measured as retained earning scaled by

Table 7.

Robustness test using alternative proxies for free cash flow total assets. FCF3 is measured as cash flow net of depreciation and the residual of Equation (1). See Appendix for variable definitions. All financial variables are winsorised at the 1 and $99 \%$ levels to reduce the influence of outliers. We control for industry fixed effects and a set of year-quarter dummies. Standard errors are clustered on both firm and quarter level. $t$-statistics are reported in parentheses. $*$, ** and *** indicate significance at the 10,5 and $1 \%$ levels, respectively

elections are also held in the fourth quarter (exactly in December) like US gubernatorial elections, the third quarter of the election years is regarded as the period of high EPU. We also replace $Q 3$ with $Q 1, Q 2$ and $Q 4$ to examine the effect of other quarters. The coefficient of Elect reflects the effect of election cycle on firm overinvestment. The coefficient of $Q 3$ controls the effect from the cyclicality of overinvestment within a year. Finally, the coefficient of the interaction term of Elect and Q3 captures the effect of EPU on overinvestment, which is the coefficient of our interest. We expect $\beta_{1}$ to be negative.

Table 8 presents the results of both the linear probability model and the logit model. The coefficients of $Q 1 \times \mathrm{EPU}, \mathrm{Q} 2 \times \mathrm{EPU}$ and $Q 3 \times \mathrm{EPU}$ are all negative and statistically significant. This indicates that compared with the quarters in a year with no election, overinvestment significantly decreases in the quarter before an upcoming election in December. By contrast, the coefficient of the interaction term of $Q 4$ is positive, which implies that uncertainty decreases because of the end of the election, thereby leading to the rebound of overinvestment.

We proceed to investigate the heterogenous effects of EPU on overinvestment using the model of Equation (5). We add a three-way interaction term regarding Elect, Q3 and Het on Equation (4). We use both the linear probability model and the logit model to estimate Equation (5). Results in Table 9 are consistent with our previous findings. For the sake of space, we only present the heterogenous effects regarding $Q 3$ [13].

$$
\begin{aligned}
\text { OverI }_{i, t}= & \alpha_{1}+\beta_{1} \text { Elect } \times Q 3+\beta_{2} \text { Elect } \times Q 3 \times \text { Het }+\beta_{3} \text { Elect }+\beta_{4} Q 3+\varphi C_{i, t-1}+\eta_{k}+\delta_{t} \\
& +\varepsilon_{i, t} .
\end{aligned}
$$

\section{Conclusion}

While overinvestment as investment distortion is one of the important topics in corporate finance, few studies examine overinvestment under uncertainty. This study makes contributions to the literature by examining the relationship between firm overinvestment 


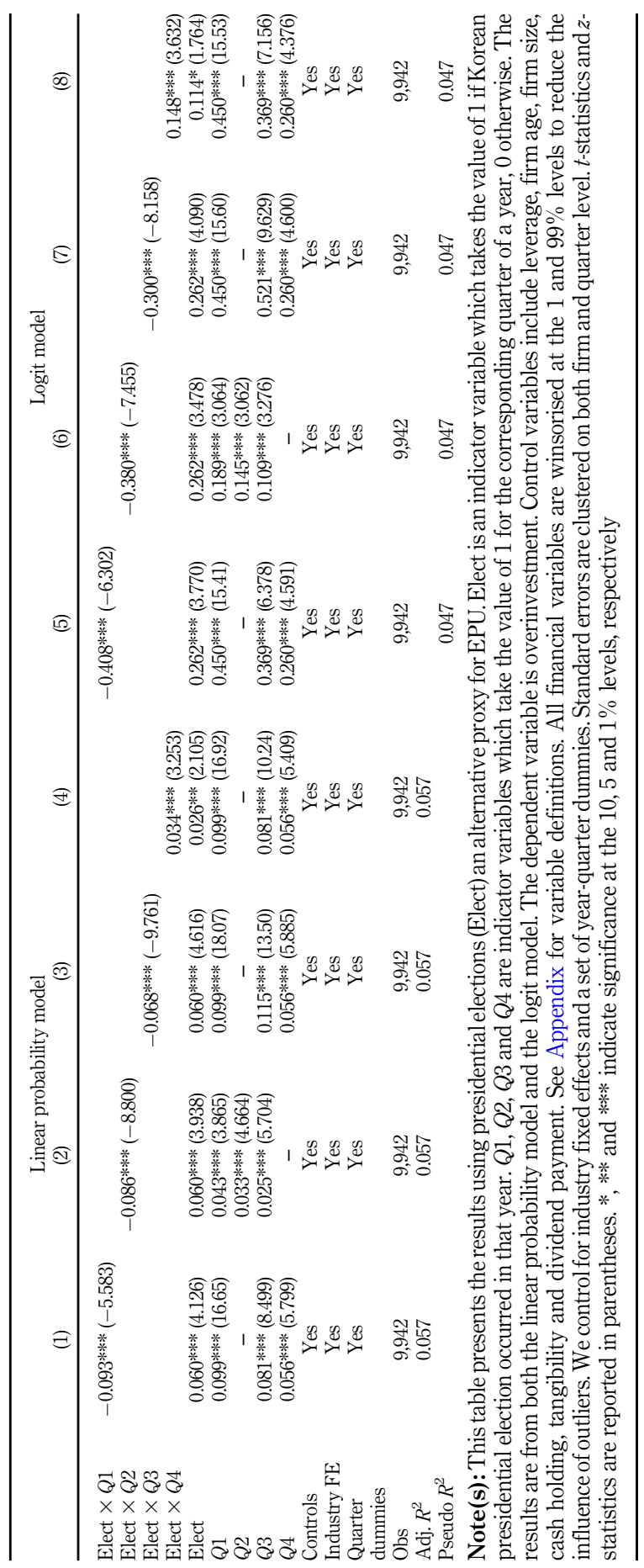

EPU and overinvestment

313

Table 8.

Robustness test using presidential elections as the proxy for EPU 
JDQS

29,4

314

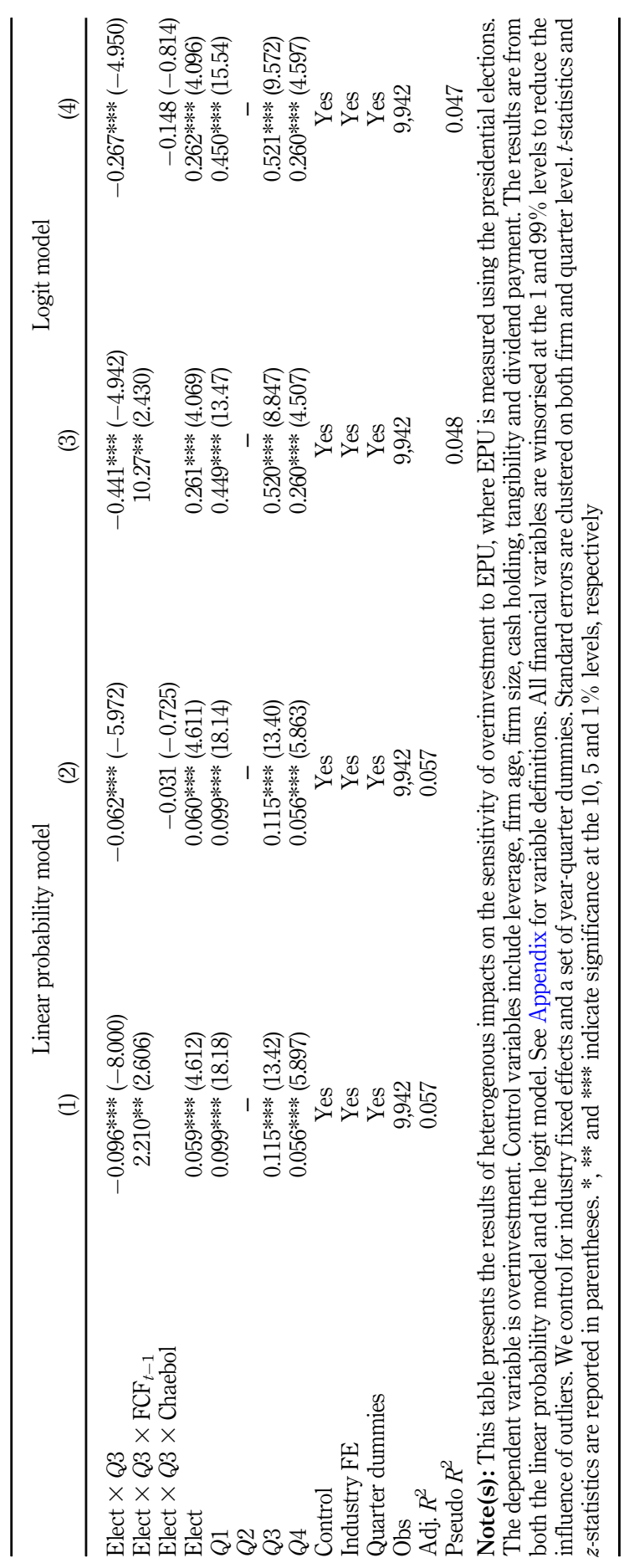

Table 9.

Robustness test for the impact of crosssectional heterogeneities 
and EPU instead of policy or inflation uncertainty. When examining corporate overinvestment, we need to incorporate free cash flow because it is a main determinant of overinvestment. We show that there is the heterogenous effect of EPU on overinvestment across free cash flow. Moreover, we introduce Chaebol firms when analyzing the sensitivity of overinvestment to EPU. Consistent with the recent studies, we find that there is no significant difference in the effect of EPU on overinvestment between Chaebol and non-Chaebol firms. While we focus on EPU in the Korean economy, our study can be extended by examining whether the heterogenous effects exist in other countries. We leave this extension to future research.

\section{EPU and overinvest-} ment

\section{Notes}

1. Previous studies suggest some characteristics of Chaebol that are related to overinvestment (e.g. Shin and Park, 1999; Ferris et al., 2003), whereas recent studies argue that many of these characteristics have been disappearing (e.g. Borensztein and Lee, 2002; Lee et al., 2009).

2. This result is controversial because several studies suggest that investment-free cash flow sensitivity disappear after controlling measurement error in Tobin's $q$ as a proxy for growth opportunities (Erickson and Whited, 2000).

3. Dataguide is one of the most well-known databases in Korea, which is provided by the Korea Listed Companies Association.

4. To enhance the monitoring of Korean business conglomerates known as Chaebol firms, the KFTC started to disclose the information about them since 2001.

5. The index of EPU is available on the website (https://www.policyuncertainty.com/).

6. The six Korean newspapers are Donga Ilbo, Kyunghyang, Maeil Economic, Hankyoreh, Hankook Ilbo and Korea Economic Daily.

7. We select data that has at least 20 observations on the basis of quarter-industry.

8. Richardson (2006) develops a measure of firm-level free cash flow. We use this measure for a robustness test.

9. The data of Chaebol is presented on an annual basis because the information related to Chaebol firms is reported annually.

10. This impact is calculated as $0.023 \times 0.589 /(-0.147)$.

11. To identify this firm-specific characteristic, we repeat the regression using all the combinations of control variables. We find that the effect of Chaebol is significant when we consider all the control variables except firm size, and as long as we control for firm size, the significance of Chaebol effect disappears.

12. The gubernatorial election in the US is held in November.

13. We also estimate Equation (5) for $Q 1$ and $Q 2$ and find similar (unreported) results.

\section{References}

Abel, A.B. (1983), "Optimal investment under uncertainty”, American Economic Review, Vol. 73 No. 1, pp. 228-233.

Ahuja, G. and Novelli, E. (2017), "Activity overinvestment: the case of R\&D”, Journal of Management, Vol. 43 No. 8, pp. 2456-2468.

Baek, J.S., Kang, J.K. and Park, K.S. (2004), "Corporate governance and firm value: evidence from the Korean financial crisis", Journal of Financial Economics, Vol. 71 No. 2, pp. 265-313.

Baker, S.R., Bloom, N. and Davis, S.J. (2016), "Measuring economic policy uncertainty", Quarterly Journal of Economics, Vol. 131 No. 4, pp. 1593-1636. 
JDQS 29,4

Bernanke, B. (1983), "Irreversibility, uncertainty, and cyclical investment", Quarterly Journal of Economics, Vol. 98 No. 1, pp. 85-106.

Bhagat, S., Moyen, N. and Suh, I. (2005), "Investment and internal funds of distressed firms", Journal of Corporate Finance, Vol. 11 No. 3, pp. 449-472.

Biddle, G.C., Hilary, G. and Verdi, R.S. (2009), "How does financial reporting quality relate to investment efficiency?", Journal of Accounting and Economics, Vol. 48 No. 2, pp. 112-131.

Bloom, N., Bond, S. and Van Reenen, J. (2007), "Uncertainty and investment dynamics", Review of Economic Studies, Vol. 74 No. 2, pp. 391-415.

Borensztein, E. and Lee, J.W. (2002), "Financial crisis and credit crunch in Korea: evidence from firmlevel data", Journal of Monetary Economics, Vol. 49 No. 4, pp. 853-875.

Bulan, L.T. (2005), "Real options, irreversible investment and firm uncertainty: new evidence from US firms", Review of Financial Economics, Vol. 14 Nos 3-4, pp. 255-279.

Caballero, R.J. (1991), "On the sign of the investment-uncertainty relationship", American Economic Review, Vol. 81 No. 1, pp. 279-288.

Duchin, R., Ozbas, O. and Sensoy, B.A. (2010), "Costly external finance, corporate investment, and the subprime mortgage credit crisis", Journal of Financial Economics, Vol. 97 No. 3, pp. 418-435.

Erickson, T. and Whited, T.M. (2000), "Measurement error and the relationship between investment and q", Journal of Political Economy, Vol. 108 No. 5, pp. 1027-1057.

Fazzari, S., Hubbard, R.G. and Petersen, B. (1988), "Investment, financing decisions, and tax policy", American Economic Review, Vol. 78 No. 2, pp. 200-205.

Ferris, S.P., Kim, K.A. and Kitsabunnarat, P. (2003), "The costs (and benefits?) of diversified business groups: the case of Korean chaebols", Journal of Banking and Finance, Vol. 27 No. 2, pp. 251-273.

Goh, J., Choi, W. and Cho, J. (2016), “Changes in chaebol firms' overinvestment after the Asian financial crisis: a long-term perspective”, Asia-Pacific Journal of Accounting and Economics, Vol. 23 No. 1, pp. 75-111.

Gul, F.A. and Tsui, J.S.L. (1997), "A test of the free cash flow and debt monitoring hypotheses: evidence from audit pricing", Journal of Accounting and Economics, Vol. 24 No. 2, pp. 219-237.

Gulen, H. and Ion, M. (2016), "Policy uncertainty and corporate investment", Review of Financial Studies, Vol. 29 No. 3, pp. 523-564.

Harford, J. (1999), “Corporate cash reserves and acquisitions”, Journal of Finance, Vol. 54 No. 6, pp. 1969-1997.

Irawan, D. and Okimoto, T. (2021), "Overinvestment and macroeconomic uncertainty: evidence from renewable and non-renewable resource firms", Journal of Economic Dynamics and Control, Vol. 126, p. 103973.

Jens, C. (2017), "Political uncertainty and investment: causal evidence from US gubernatorial elections", Journal of Financial Economics, Vol. 124 No. 3, pp. 563-579.

Jensen, M.C. (1986), "Agency costs of free cash flow, corporate finance, and takeovers", American Economic Review, Vol. 76 No. 2, pp. 323-329.

Julio, B. and Yook, Y. (2012), "Political uncertainty and corporate investment cycles", Journal of Finance, Vol. 67 No. 1, pp. 45-83.

Kallapur, S. (1994), "Dividend payout ratios as determinants of earnings response coefficients: a test of the free cash flow theory", Journal of Accounting and Economics, Vol. 17 No. 3, pp. 359-375.

Leahy, J.V. and Whited, T.M. (1996), "The effect of uncertainty on investment: some stylized facts", Journal of Money, Credit and Banking, Vol. 28 No. 1, pp. 64-83.

Lee, S., Park, K. and Shin, H.H. (2009), "Disappearing internal capital markets: evidence from diversified business groups in Korea", Journal of Banking and Finance, Vol. 33 No. 2, pp. 326-334. 
Lehn, K. and Poulsen, A. (1989), "Free cash flow and stockholder gains in going private transactions", Journal of Finance, Vol. 44 No. 3, pp. 771-787.

Liu, X. (2013), "The value of holding scarce wind resource-a cause of overinvestment in wind power capacity in China”, Energy Policy, Vol. 63, pp. 97-100.

Pástor, L. and Veronesi, P. (2013), "Political uncertainty and risk premia", Journal of Financial Economics, Vol. 110 No. 3, pp. 520-545.

Panousi, V. and Papanikolaou, D. (2012), "Investment, idiosyncratic risk, and ownership", Journal of Finance, Vol. 6 No. 3, pp. 1113-1148.

Richardson, S. (2006), “Over-investment of free cash flow”, Review of Accounting Studies, Vol. 11 Nos 2-3, pp. 159-189.

Shin, H.H. and Park, Y.S. (1999), "Financing constraints and internal capital markets: evidence from Korean 'chaebols", Journal of Corporate Finance, Vol. 5 No. 2, pp. 169-191.

Stulz, R. (1990), "Managerial discretion and optimal financing policies", Journal of Financial Economics, Vol. 26 No. 1, pp. 3-27.

Wang, Y., Chen, C.R. and Huang, Y.S. (2014), "Economic policy uncertainty and corporate investment: evidence from China", Pacific-Basin Finance Journal, Vol. 26, pp. 227-243.

Wang, Y., Chen, C.R., Chen, L. and Huang, Y.S. (2016), "Overinvestment, inflation uncertainty, and managerial overconfidence: firm level analysis of Chinese corporations", North American Journal of Economics and Finance, Vol. 38, pp. 54-69. 


\begin{tabular}{|c|c|c|}
\hline \multirow{4}{*}{$\begin{array}{l}\text { JDQS } \\
29,4\end{array}$} & \multicolumn{2}{|l|}{ Appendix } \\
\hline & Inv & Total investment is calculated as firm's capital expenditure scaled by the total assets \\
\hline & & Sales growth is the difference of sales between quarter $t$ and $t-1$, scaled by sales of quarter $t$ \\
\hline & OverI & $\begin{array}{l}\text { Overinvestment is an indicator variable that takes on the value of } 1 \text { if the deviation between the } \\
\text { actual and the expected investment in Equation (1) is positive, } 0 \text { otherwise }\end{array}$ \\
\hline \multirow{17}{*}{318} & EPU & An index of economic policy uncertainty (EPU) made by Baker et al. (2016) based on the number \\
\hline & & $\begin{array}{l}\text { of newspaper articles including the words related to uncertainty and policy. We calculate the } \\
\text { arithmetic average of the monthly levels of the index within each quarter and take the natural } \\
\text { logarithm of it (Gulen and Ion, 2016) }\end{array}$ \\
\hline & GDPgrowth & GDP growth is the quarterly growth in real GDP of Korea \\
\hline & $T q$ & $\begin{array}{l}\text { Tobin's } q \text { is measured as the market value of a firm's equity and debt divided by the book value } \\
\text { of a firm's total assets }\end{array}$ \\
\hline & Size & Firm size is the natural logarithm of total assets \\
\hline & Lev & Leverage is the sum of the book value of total debt divided by book value of total assets \\
\hline & Age & Age is the natural logarithm of the years that the firm has been listed on KOSPI \\
\hline & Cash & Cash holding is measured by the sum of cash and cash equivalents scaled by total assets \\
\hline & Tang & Tangibility is measured by tangible assets scaled by total assets \\
\hline & Div & Dividend is an indicator variable that takes the value of 1 if a firm pays dividend in a given year \\
\hline & & Internal finance is measured as the sum of net profit and depreciation scaled by total assets \\
\hline & Chaebol & $\begin{array}{l}\text { Chaebol is an indicator variable which takes value } 1 \text { if a firm belongs to Chaebol group in a } \\
\text { given year, } 0 \text { otherwise }\end{array}$ \\
\hline & OverI2 & $\begin{array}{l}\text { OverI } 2 \text { is an indicator variable that takes on the value of } 1 \text { if the deviation between the actual } \\
\text { and the expected investment in Equation (5) is positive, } 0 \text { otherwise }\end{array}$ \\
\hline & OverI3 & $\begin{array}{l}\text { OverI3 is an alternative measure of overinvestment following Richardson (2006), which is based } \\
\text { on the residuals of an equation where investment is a function of Tobin's } q \text {, cash holding, firm } \\
\text { age, firm size, stock return and firm investment of the prior quarter, quarter effects and industry } \\
\text { effects. OverI3 takes the value of } 1 \text { if the residual in the equation is positive, } 0 \text { otherwise }\end{array}$ \\
\hline & FCF3 & FCF3 is measured as retained earning scaled by total assets \\
\hline & FCF3 & $\begin{array}{l}\text { FCF3 is measured by subtracting depreciation and the residual of Equation (1) from operating } \\
\text { cash flow }\end{array}$ \\
\hline & Election & $\begin{array}{l}\text { Election is an indicator variable which takes the value of } 1 \text { if Korean presidential election } \\
\text { occurred in that year, } 0 \text { otherwise }\end{array}$ \\
\hline $\begin{array}{l}\text { Table A1. } \\
\text { Variable definitions }\end{array}$ & $Q 1-Q 4$ & $\begin{array}{l}Q 1, Q 2, Q 3 \text { and } Q 4 \text { are indicator variables which take the value of } 1 \text { for the corresponding } \\
\text { quarter of a year, } 0 \text { otherwise }\end{array}$ \\
\hline
\end{tabular}

\section{Corresponding author}

Hwa-Sung Kim can be contacted at: fstar@khu.ac.kr

For instructions on how to order reprints of this article, please visit our website:

www.emeraldgrouppublishing.com/licensing/reprints.htm

Or contact us for further details: permissions@emeraldinsight.com 